\title{
Gender Inequality, Stress Exposure, and Well-Being among Academic Faculty
}

\author{
Marta Elliott ${ }^{1}$ \& Sarah J. Blithe ${ }^{1}$ \\ ${ }^{1}$ College of Liberal Arts, University of Nevada, Reno, Reno, NV, United States \\ Correspondence: Marta Elliott, Department of Sociology, 1664 N. Virginia St./MS 300, University of Nevada, Reno, \\ Reno, NV 89557, US.
}

Received: November 8, 2020

Accepted: December 3, 2020

Online Published: December 9, 2020

doi:10.5430/ijhe.v10n2p240

URL: https://doi.org/10.5430/ijhe.v10n2p240

\begin{abstract}
Gender inequalities in salary, rank and access to leadership positions characterize institutions of higher education and disadvantage women faculty. Differential exposure to noxious working conditions and restricted access to social resources may underlie these inequalities by detracting from women faculty's well-being, thereby perpetuating the status quo. This study applies stress process theory to analyze this inequitable state of affairs, treating gender as a social status in higher education that predicts differential exposure to stressors and access to resources. Stressors and resources, in turn, predict faculty well-being. Stressors include micro-aggressions and work-life conflict, and resources include collegiality with peers and support from administrators. Survey data were collected from academic faculty at a mid-sized Western university in the U.S. Results indicate that women faculty experience micro-aggressions and work-life conflict more often than men, and report less supportive relationships with their deans. Moreover, microaggressions and work-life conflict are positively associated with psychological distress and job dissatisfaction, while dean support has the opposite associations. Open-ended responses supplement the quantitative findings with vivid examples of how these phenomena play out in individual faculty members' lives. Implications for how institutions of higher education might introduce change to address these findings are discussed.
\end{abstract}

Keywords: gender inequality, academic faculty, stressors, resources, well-being

\section{Introduction}

Gender inequalities are rampant in institutions of higher education, disadvantaging women faculty members in myriad ways that detract from their well-being. In the U.S., women faculty in higher education have lower salaries than men at all ranks and types of institutions (AAUP, 2018; Clery \& Christopher, 2010; Shulman et al., 2017; Thornton, 2010). They are also less likely to be tenured (AAUP, 2018; Box-Steffensmeier et al., 2015; Perna, 2005; Wolfinger, Mason, \& Goulden, 2008; Weisshaar, 2017) promoted (Ginther \& Hayes, 2003; Perna, 2001), to be full professors (AAUP, 2018; Clery \& Christopher, 2010; Misra, Hickes Lundquist, Holmes, \& Agiomavritis, 2011), or to be college presidents (American Council on Education, 2017; Cook, 2012). Prejudice towards and discrimination against women are known sources of these persistent inequalities (Barbezat \& Hughes, 2005; Lips, 2013; Shen, 2013).

Stereotypes of successful leaders are becoming more androgynous over time yet remain predominantly masculine (Koenig, Eagly, Mitchell, \& Ristikari, 2011). Gender stereotypes of academic faculty describe women as less competent, less likely to succeed, and less likely to be good leaders than men (Schmaling, 2007), which may explain why students evaluate women faculty more negatively than men (Boring, 2017; Hirshfield, 2014; MacNell, Driscoll, \& Hunt, 2015; Mengel, Sauermann, \& Zolitz, 2018). Women do more internal service than men (Guarino \& Borden, 2017) and service is valued less than research in promotion and tenure decisions (Misra et al., 2011; Monroe, Ozyurt, Wrigley, \& Alexander, 2008; Schimanski \& Alperin, 2018).

Women faculty's multiple disadvantages may well detract from their well-being by elevating psychological distress and job dissatisfaction. Distress and dissatisfaction, in turn, may reduce productivity and diminish job performance and organizational commitment (Aydogdu \& Asikgil, 2011; Colligan \& Higgins, 2006; Dovidio, 2001; Judge et al., 2001; Robertson, Birch, \& Cooper, 2012), thereby perpetuating gender inequalities. Careful analysis of gender differences in working conditions and how they impact well-being is critical to informing proactive policy changes in higher education. Therefore, this study focuses on how working conditions that disadvantage women are related to distress and job dissatisfaction among academic faculty, testing hypotheses derived from stress process theory. 


\section{Stress Process Theory: Stressors, Resources, and Faculty Well-being}

Stress process theory (SPT) posits that unequal positions in social hierarchies (e.g., gender in academia) predict differential exposure to stressors and differential access to resources (Pearlin, Menaghan, Lieberman, \& Mullan, 1981; Pearlin, 1989). Stressors and resources, in turn, impact well-being whereby stressors erode well-being and resources protect it. In addition, resources may function as stress buffers by reducing the effects of stressors on well-being, such as when social support helps people cope with stressful life circumstances. This study focuses on two stressors and two resources: micro-aggressions and work-life conflict, and support from leaders and collegiality with peers. In keeping with SPT, it examines whether women faculty are differentially exposed to more of these stressors and have access to fewer of these resources than do men. It then asks if stressors and resources are associated with distress and job dissatisfaction and if resources attenuate the associations between stressors and well-being.

Micro-aggressions (Sue et al., 2007) are "brief and commonplace daily verbal, behavioral, or environmental indignities, whether intentional or unintentional, that communicate hostile, derogatory, or negative slights and insults" (p. 271). There are three types. The subtlest are micro-invalidations: words or actions that "exclude, negate, or nullify the psychological thoughts, feelings, or experiential reality" (p. 274). An example of a gendered micro-invalidation occurs when people suggest the wage gap is a myth, or that women are simply paid less because they are less qualified. This behavior ignores the reality that bias and discrimination are behind an otherwise unexplainable difference in income by gender and race. The second form of micro-aggressions, micro-insults are "communications that convey rudeness and insensitivity" (p. 274). An example of a micro-insult occurs when people say "that's so gay," to imply something is stupid. Lastly, micro-assaults are outright discrimination, "characterized primarily by a verbal or nonverbal attack meant to hurt the intended victim" (p. 274). An example of a micro-assault occurs when a coworker quickly gropes another and claims it was a joke.

All forms of micro-aggressions can create a hostile work environment, but are difficult to prove, especially in academia, where "academic freedom" and tenure protect a range of behaviors (Lukes and Bangs, 2014). An added complication lies in the very different sorts of micro-aggressions experienced by women at different times throughout their career. For example, newly hired tenure-track women may hear that they secured their job because of equity hiring, not because of their intelligence or accomplishment, while full professors are continually overlooked for administrative roles (Blithe \& Elliott, 2019).

Micro-aggressions also span both institutional and interpersonal interactions. In the academy, this spread suggests that women and academics of color are disadvantaged by the institution, which can, for example, pay women less and promote people who engage in abusive practices. At the same time, individual women and scholars of color experience micro-aggressions in their interpersonal lives with colleagues in everyday actions (Pittman, 2012). Both of these scenarios can increase stress and negatively impact mental health.

Most research examines micro-aggressions targeted at racial minorities and how they negatively impact mental health (Nadal et al., 2014; Ong, Burrow, Fuller-Rowell, Ja, \& Sue, 2013; Sellers \& Shelton, 2003; Torres, Driscoll, \& Burrow, 2010), although Nadal and Haynes (2012) link micro-aggressions to poor mental health among women. Perceived discrimination on the job including subtle everyday mistreatment resembling micro-aggressions has also been linked to job dissatisfaction (Deitch et al., 2003; Ensher, Grant-Vallone, \& Donaldson, 2001) and reduced research productivity among faculty of color (Eagan \& Garvey, 2015). In this study, micro-aggressions are conceptualized as phenomena that women and men experience but are more likely to be reported by women owing to their disadvantaged social status in academia and cultural sexism (Savigny, 2014).

Work-life conflict is also related to poor mental health (Amstad, Meier, Fasel, Elfering, \& Semmer, 2011; Frone, 2010; Oshio, Inoue, \& Tsutsumi, 2017) and job dissatisfaction (Amstad et al., 2011; Oshio et al., 2017) and is bidirectional. For example, faculty may miss work to care for family members or work late, limiting time to spend with family. Women more often report that family and household responsibilities interfere with employment, whereas men more often report that work responsibilities interfere with family (Fox, Fonseca, \& Bao, 2011). Similarly, family stressors predict work-life conflict among women faculty, whereas workplace stressors predict it among men (Elliott, 2008).

Unlike micro-aggressions and work-life conflict, socially supportive relationships in the workplace predict improved mental health (De Lange, Taris, Kompier, Houtman, \& Bongers, 2004; Harvey et al., 2017; Stansfeld \& Candy, 2006) and job satisfaction (Cantarelli, Belardinelli, \& Belle, 2016; Ducharme \& Martin, 2000; Harris, Winskowski, \& Engdahl, 2007). Social support may moderate (i.e., reduce) the influence of workplace stressors on mental health and job satisfaction (Frese, 1999; Moeller \& Chung-Yan, 2013; Terry, Nielsen, \& Perchard, 1993), although some studies find that its influence is primarily direct (Chou, 2015; Ducharme \& Martin, 2000; Van der Doef \& Maes, 1999). 
Social support is one means by which individuals cope with micro-aggressions (Lewis, Mendenhall, Harwood, \& Browne Huntt, 2013), especially support from individuals who accept that micro-aggressions should be taken seriously (Sue et al., 2007). Supportive colleagues and supervisors can listen empathically, potentially buffering the association between stressors and well-being, or they may provide advice, and in some cases intervene to put a stop to chronic micro-aggressive behaviors. Work-place social support may also alleviate work-life conflict (Almeida et al., 2016; Goh, Ilies, \& Wilson, 2015) such as by facilitating flexible course scheduling and encouraging the use of institutional policies that support families (Hammer, Ernst Kossek, Yragui, Bodner, \& Hanson, 2009). In contrast, without social support, stressors may lead to more distress and job dissatisfaction, and faculty may be less inclined to seek formal help in addressing in dealing with micro-aggressions or work-life conflict on the job.

\section{Conceptual Model and Hypotheses}

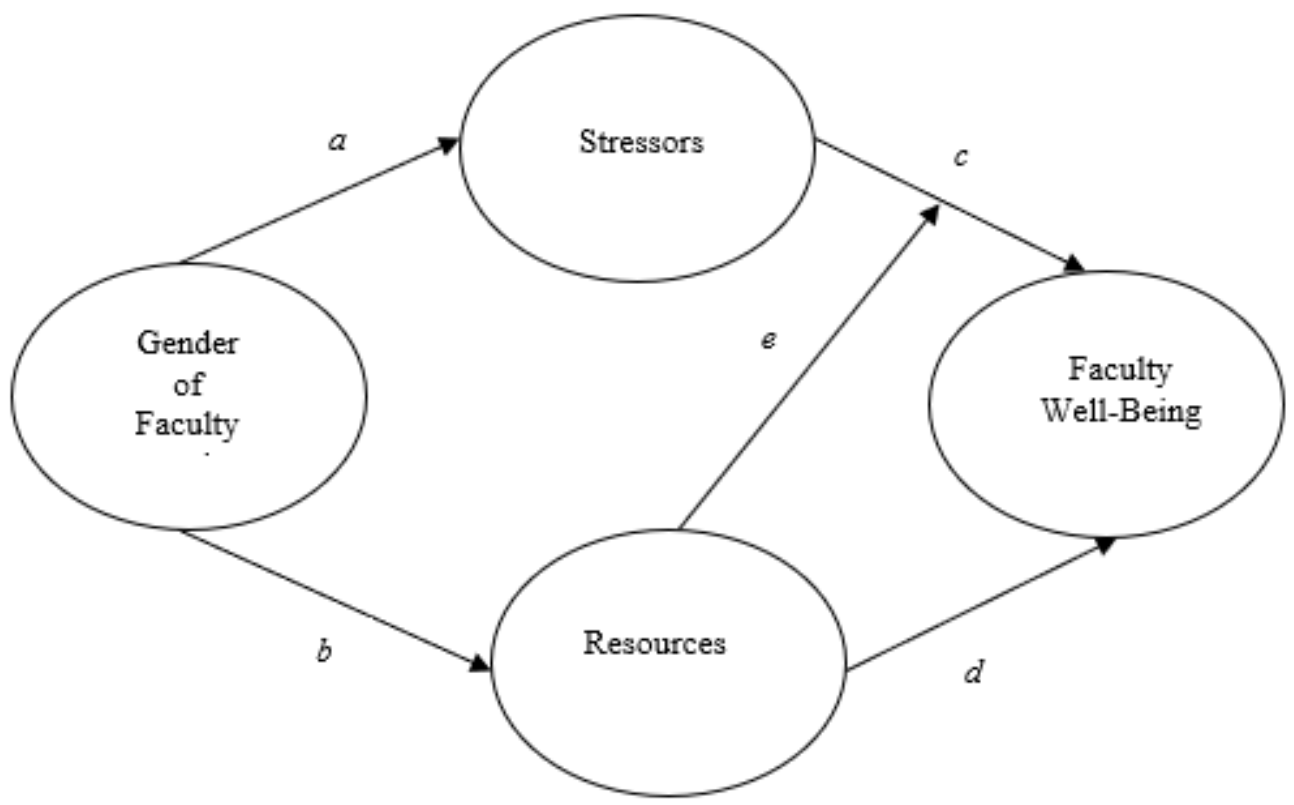

Figure 1. Conceptual Model

The conceptual model derived from stress process theory is presented in Figure 1. On the far left is social-structural position, which in this study is gender. Gender predicts exposure to stressors (path $a$ ) and access to resources (path $b$ ). Stressors predict worse well-being (path $c$ ) whereas resources predict improved well-being (path $d$ ). Lastly, resources may moderate the associations between stressors and well-being (path $e$ ). The following are formally stated hypotheses that correspond to each path in the model.

Hypothesis $a$ : Women faculty will report greater exposure to stressors than men faculty.

Hypothesis $b$ : Women faculty will report less access to resources than men faculty.

Hypothesis $c$ : Stressors will be negatively associated with well-being.

Hypothesis $d$ : Resources will be positively associated with well-being.

Hypothesis e: Resources will attenuate the associations between stressors and well-being.

\section{Data and Methods}

In the fall of 2015, an email invitation was sent to all 1051 academic faculty at a mid-sized comprehensive R2 doctoral and public university in the Western U.S. to complete a voluntary, anonymous online survey. The survey was designed to capture the following domains of the academic work environment: exposure to stressors (i.e., micro-aggressions and work-life conflict), access to supports (i.e., collegiality and support from leadership), faculty mental health and job satisfaction. In addition, it gathered categorical data on rank, tenure, gender, racial/ethnic group membership, sexual orientation, parenthood status, and eldercare responsibilities. It was exempt from Institutional Review Board review because it was deemed as of minimal risk to participants.

Fifty per cent ( $\mathrm{n}=521)$ of the faculty provided complete data. Over half of the sample identified as men (54.5\%), 10.6\% were non-tenure-track lecturers, $30.7 \%$ were assistant professors, $29.2 \%$ were associate professors, $27.4 \%$ were full 
professors, and 50.5\% were tenured. Fewer than half (40.7\%) had children under the age of 18 at home, and $17.9 \%$ were responsible for eldercare. Only $17.3 \%$ identified as a racial/ethnic minority group member, and $5.8 \%$ identified as lesbian, gay or bisexual. These characteristics were included as control variables in the multiple regression analyses. Rank and tenure were included based on the expectation that these statuses indicate greater job security and therefore less on-the-job stress. Parenthood and eldercare were included to distinguish any influence of these statuses from selfreported work-life conflict. Sexual orientation and racial/ethnic status were included based on the expectation that people who identify with sexual or racial/ethnic minority groups are exposed to more on-the-job prejudice and discrimination, which might predict greater distress and less job satisfaction (Triana, Jayasinghe, \& Pieper, 2015; Zurbrugg \& Miner, 2016).

\subsection{Measures}

Frequency of micro-aggressions $(M=1.92, S D=.63)$ was measured as the mean score for six items (alpha reliability $=.76$ ) adapted from an inventory of racial micro-aggressions developed by Mercer, Zeigler-Hill, Wallace, and Hayes (2011) to fit an academic setting and to apply to women and men. Faculty rated how often on a scale from 1 (never) to 5 (always): (1) "My opinion is discounted in committee meetings," (2) "People ask me to do certain tasks at work because of my gender," (3) "Co-workers act as if I need their help when I can do my job just fine by myself," (4) "Coworkers make inappropriate comments about my appearance," (5) "Students refer to me by my first name or as Mr. or Mrs. although I prefer Doctor or Professor," and (6) "Co-workers express surprise at how well I do my job."

Work-life conflict $(M=2.88, S D=.80)$ was measured as the mean score across four items (alpha reliability $=.73$ ) rated from 1 (strongly disagree) to 5 (strongly agree): (1) "Having children is not compatible with my career," (2) "It is hard for me to prioritize my family over my job," (3) "I cannot make time for my personal interests and relationships outside of work," and (4) "I worry about my family while I am at work."

Socially supportive relationships were assessed in terms of collegiality with peers, support from one's department chair, and support from one's college dean. Collegiality $(M=3.58, S D=.84)$ was measured with the mean of four items (alpha reliability $=.77$ ) rated from 1 (strongly disagree) to 5 (strongly agree): (1) "I enjoy working around my colleagues," (2) "I feel included when my colleagues do things together socially," (3) "The social environment in my department is not conducive to getting my work done," (reverse-coded) and (4) "Socializing with colleagues outside of work does not fit well with my lifestyle" (reverse-coded). Support from one's department chair $(M=3.65, S D=$ $1.34)$ and dean $(M=2.99, S D=1.30)$ were measured with the means of three parallel items (alpha reliabilities $=.94$ and .91, respectively) from 1 (strongly disagree) to 5 (strongly agree): (1) "My department chair/dean is a strong advocate for me and my work," (2) "My department chair/dean treats all faculty in our department equally," and (3) "I feel comfortable going to my department chair/dean if I am having a problem with my job."

Psychological distress $(M=2.02, S D=.59)$ was measured as the mean score for five items (alpha reliability $=.79)$ following Stewart, Ware, Sherbourne, and Wells (1992). Sample items include "I have been calm and peaceful" and "I have been downhearted and blue" ranging from 1 (none of the time) to 5 (all of the time). Job satisfaction $(M=3.27$, $S D=.85)$ was measured by a single item: "How satisfied are you with your job, as a whole?" $(1=$ very dissatisfied to $5=$ very satisfied).

At the end of the survey, faculty were asked if they had "any comments on any of the issues addressed in this questionnaire or have anything to add that you were not asked about." These open-ended responses were reviewed to identify comments relevant to the constructs analyzed in this study. A summary of them along with illustrative quotes are presented at the end of the results section to contextualize the quantitative findings.

\subsection{Statistical Analysis}

First, male and female faculty were compared with the two-tailed chi-square test of independence to test whether or not proportions varied significantly by gender across categorical variables (e.g., percent lecturer). Second, male and female faculty were compared on continuous measures by conducting independent sample t-tests for equality of means to test hypotheses a and b. Next, psychological distress and job satisfaction were regressed on micro-aggressions, work-life conflict, collegiality, chair support, and dean support, and the control variables to test hypotheses c and d. Lastly, interaction terms were created between each type of stressor (micro-aggressions or work-life conflict) and each type of resource (collegiality, chair support, and dean support), resulting in six interaction terms to test whether or not social support buffers the associations between stressors and well-being (hypothesis e). Each interaction was entered individually into the full regression models for distress and job satisfaction. 


\section{Results}

\subsection{Quantitative Findings}

Table 1. Results of chi-square test and descriptive statistics by sex

\begin{tabular}{lccr}
\hline & Women, $\mathrm{n}=237$ & Men, $\mathrm{n}=284$ & $\mathrm{Chi}^{2}$ df \\
\hline Lecturer & $35(14.8 \%)$ & $20(7.0 \%)$ & $8.166 * * 1$ \\
Assistant Professor & $76(32.1 \%)$ & $84(29.6 \%)$ & $.376 \quad 1$ \\
Associate Professor & $74(31.2 \%)$ & $78(27.5 \%)$ & $.883 \quad 1$ \\
Full Professor & $48(20.3 \%)$ & $95(33.5 \%)$ & $11.30 * * * 1$ \\
Tenured & $110(46.4 \%)$ & $153(53.9 \%)$ & 2.8761 \\
Racial/ethnic minority & $32(13.5 \%)$ & $58(20.4 \%)$ & $4.330 * 1$ \\
Lesbian, gay or bisexual & $20(8.4 \%)$ & $10(3.5 \%)$ & $5.757 * 1$ \\
Child(ren) under 18 & $88(37.1 \%)$ & $124(43.7 \%)$ & $2.283 \quad 1$ \\
Eldercare & $52(21.9 \%)$ & $41(14.4 \%)$ & $4.961 * 1$ \\
& & & \\
\hline
\end{tabular}

Note. $\quad * * * p<.001 \quad * * p<.01 * p<.05$

As shown in Table 1 , men $(N=284)$ and women $(N=237)$ (no faculty identified otherwise) differed in their proportional representation across several categories (see Table 1). Women were more likely to be lecturers $(14.8 \%)$ than men $(7 \%)\left(\chi^{2}(1)=8.16, p=.004\right)$, and less likely to be full professors $(20.3 \%$ vs. $33.5 \%)\left(\chi^{2}(1)=11.30, p=\right.$ .001 ) whereas men and women were equally likely to be assistant professors, associate professors, and to be tenured. These gender differences are similar to the entire academic faculty of this university in the fall of 2015 , at which time $55 \%$ of lecturers were women while $73 \%$ of full professors were men.

Women were less likely than men to identify as members of racial/ethnic minority groups $(13.5 \%$ vs. $20.4 \%)\left(\chi^{2}(1)\right.$ $=4.33, p=.037)$ and more likely to identity as lesbian, gay, or bisexual $(8.4 \%$ vs. $3.5 \%)(\chi 2(1)=5.76, p=.016)$. There were no gender differences in having children at home, but women reported greater responsibility for eldercare than men $(21.9 \%$ vs. $14.4 \%)(\chi 2(1)=4.96, p=.026)$.

Table 2. Results of T-Test and Descriptive Statistics for Scales by Sex

\begin{tabular}{|c|c|c|c|c|c|c|c|c|}
\hline & \multicolumn{2}{|c|}{ Male, $n=284$} & \multicolumn{3}{|c|}{ Female, $n=237$} & \multirow[b]{2}{*}{$\mathrm{CI}$} & \multirow[b]{2}{*}{$\mathrm{t}$} & \multirow[b]{2}{*}{ df } \\
\hline & M & SD & M & SD & $95 \%$ & & & \\
\hline Micro-aggressions & 1.73 . & 52 & 2.14 & .69 & .31 & .52 & $7.611 * * *$ & 519 \\
\hline Work and family conflict & 2.75 & .73 & 3.04 & .85 & .15 & .42 & $4.084 * * *$ & 519 \\
\hline Collegial relationships & 3.63 & .83 & 3.52 & .86 & -.26 & .03 & -1.498 & 519 \\
\hline Support from the department chair & 3.69 & 1.29 & 3.60 & 1.40 & -.32 & .14 & -.750 & 519 \\
\hline Support from the college dean & 3.11 & 1.28 & 2.84 & 1.32 & -.49 & -.05 & $-2.366^{*}$ & 519 \\
\hline Psychological distress & 2.00 & .57 & 2.05 & .62 & -.06 & .14 & .829 & 519 \\
\hline Job satisfaction & 3.27 & .84 & 3.27 & .86 & -.15 & .15 & .001 & 519 \\
\hline
\end{tabular}

Note. $* * * p<.001 * * p<.01 * p<.05$

Men and women reported differential exposure to workplace stressors (see Table 2) wherein women reported more frequent exposure to micro-aggressions $(M=2.14, S D=.69)$ than men $(M=1.73, S D=.52 ; t(519)=7.801, p<.001)$ 
and more work-life conflict $(M=3.04, S D=.85)$ than men $(M=2.75, S D=.73 ; t(519)=4.139, p<.001)$, consistent with hypothesis a. There were no gender differences in collegiality or chair support but women reported less support from their dean $(M=2.84, S D=1.32)$ than men $(M=3.11, S D=1.28 ; t(519)=-2.366, p=.018)$, providing mixed support for hypothesis $\mathrm{b}$. There were no gender differences in psychological distress or job satisfaction.

Table 3. Regression Analysis of Psychological Distress and Job Satisfaction ( $\mathrm{N}=521)$

\begin{tabular}{lllllllll}
\hline & Distress & & \multicolumn{7}{c}{ Job Satisfaction } \\
& $B$ & $S E B$ & $B$ & $S E B$ & $B$ & $S E B$ & $B$ & $S E B$ \\
\hline Micro-aggressions & $.107^{* *}$ & .042 & $.133^{* *}$ & .044 & $-.139 * *$ & .050 & $-.190^{* * *}$ & .052 \\
Work and family conflict & $.202^{* * *}$ & .032 & $.205^{* * *}$ & .032 & $-.136^{* * *}$ & .038 & $-.142^{* * *}$ & .038 \\
Collegial relationships & -.044 & .034 & -.042 & .034 & $.235^{* * *}$ & .040 & $.232 * * *$ & .040 \\
Support from chair & -.031 & .022 & -.027 & .022 & $.098^{* * *}$ & .026 & $.092^{* * *}$ & .026 \\
Support from the dean & $-.042^{*}$ & .021 & $-.045^{*}$ & .021 & $.199 * * *$ & .025 & $.204 * * *$ & .025 \\
Lecturer & -.028 & .111 & .000 & .111 & $.279 *$ & .132 & .225 & .132 \\
Assistant professor & .142 & .094 & .158 & .094 & -.026 & .112 & -.057 & .112 \\
Associate professor & .104 & .064 & .117 & .064 & -.094 & .077 & -.121 & .076 \\
Tenured & -.028 & .082 & -.027 & .082 & -.029 & .097 & -.030 & .096 \\
Racial/ethnic minority & -.039 & .063 & -.056 & .063 & -.070 & .075 & -.037 & .075 \\
Lesbian/gay/bisexual & .023 & .104 & .037 & .104 & -.221 & .124 & $-.247 *$ & .123 \\
Child(ren) at home & -.022 & .051 & -.027 & .050 & -.040 & .060 & -.030 & .060 \\
Eldercare responsibilities & -.055 & .062 & -.043 & .062 & -.005 & .074 & -.028 & .074 \\
Male & & & $.104 *$ & .052 & & & $-.204 * * *$ & .061 \\
Constant & $1.598 * * *$ & .195 & $1.462 * * *$ & .206 & $2.198^{* * *}$ & .233 & $2.463 * * *$ & .244 \\
\hline Adjusted R ${ }^{2}$ & .172 & & .177 & & .432 & & .443 & \\
\hline Note. $* * * p<.001$ & $* * p<.01 * p<.05$ & & & & & &
\end{tabular}

A multiple linear regression was calculated to predict psychological distress and job satisfaction based on work-place stressors, social supports, interactions between the two, and the control variables. Table 3 presents regressions of distress and job satisfaction on all the independent variables. Two regressions of each dependent variable are presented, the first without gender in the model and the second including gender to illustrate how the omission of gender suppressed the effect of micro-aggressions on distress and job satisfaction.

Micro-aggressions were positively related to distress $(B=.11, S E=.04, p<.01)$ and negatively related to job satisfaction $(B=-.14, S E=.05, p<.01)$ when gender was not included, as predicted by hypothesis $\mathrm{c}$. When gender was added, the positive association with distress increased by $24 \%(B=.13, S E=.04, p<.01)$ and the negative association with job satisfaction $(B=-.19, S E=.05, p<.001)$ increased by $37 \%$. Moreover, men reported significantly higher levels of distress $(B=.10, S E=.05, p<.05)$ and less job satisfaction $(B=-.20, S E=.06, p<.001)$ than women in the multiple regression, even though there is no significant difference between men and women in average levels of distress or job satisfaction. The latter result suggests that men might be more distressed and less satisfied with their jobs than women were it not for their lower exposure to micro-aggressions.

The remaining coefficients in the models changed only slightly when gender was added to the model, and results are presented next are from the models including gender. Work-life conflict was positively associated with distress $(B=$ $.21, S E=.03, p<.001)$, and negatively associated with job satisfaction $(B=-.14, S E=.04, p<.001)$ net of the association between being male and each dependent variable, consistent with hypothesis $c$. However, there was mixed support for hypothesis $\mathrm{d}$. While collegiality and chair support were unrelated to distress, dean support was negatively associated with it $(B=-.04, S E=.02, p<.05)$. Nevertheless, collegiality $(B=.23, S E=.04, p<.001)$, chair support $(B=.09, S E=.03, p<.001)$, and dean support $(B=.21, S E=.03, p<.001)$ were all positively associated with job satisfaction. Identifying as lesbian, gay or bisexual was negatively associated with job satisfaction $(B=-.25, S E=.12$, $p<.05)$. 
Next, a series of twelve regressions was estimated, six of distress and six of job satisfaction to test hypothesis e (full results available upon request). Each regression included one interaction term between a workplace stressor (i.e., micro-aggressions or work-life conflict) and a resource (dean support, chair support, or collegiality). There was one significant interaction between a stressor and resource predictive of distress: the positive association between worklife conflict and distress was attenuated by dean support, indicating that support from one's dean may buffer the ill effects of work-life conflict on distress. However, none of the interactions between stressors and resources were significantly related to job satisfaction.

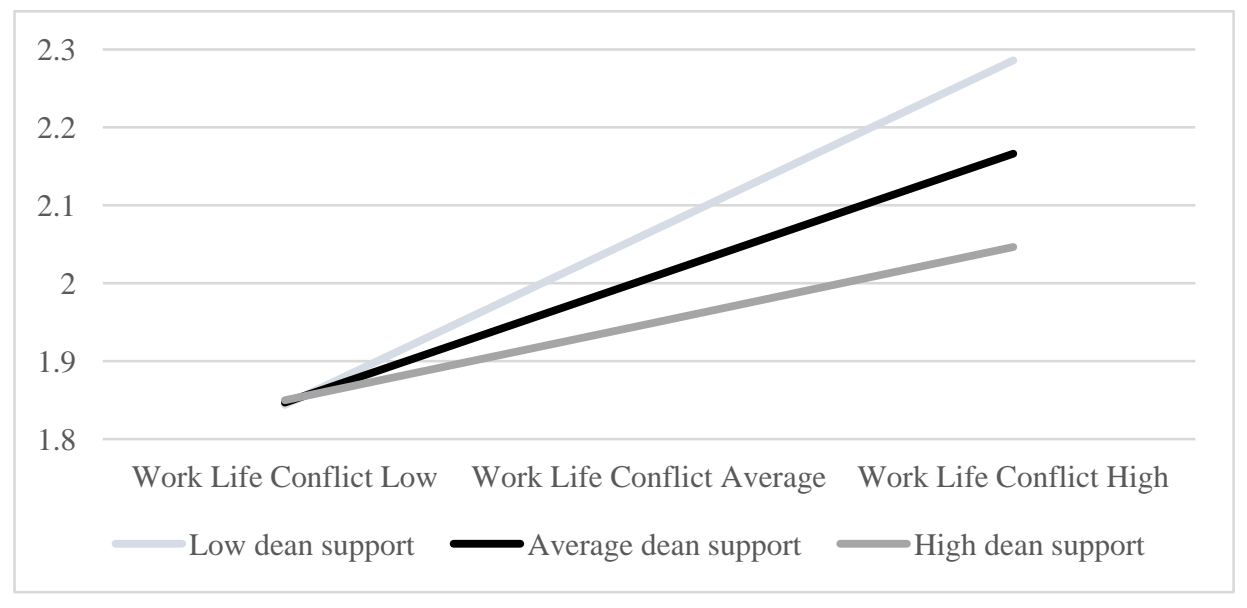

Figure 2. Dean support moderates work-life conflict association with distress

Figure 2 depicts the association between work-life conflict and distress at three levels of dean support: low (one SD below the mean), average (the mean), and high (one SD above the mean). When work-life conflict is low (one SD below the mean), there is no difference in predicted distress levels according to dean support. However, when worklife conflict is high (one SD above the mean), the predicted value of distress is .25 points higher for those with low dean support than for those with high dean support, a difference of almost one-half the standard deviation of distress (which was .59).

\subsection{Qualitative Findings}

Turning now to the open-ended remarks, 162 of the 521 respondents wrote something in response to being asked for additional comments. Only 18 mentioned gender, and 15 came from women. Several mentioned conditions that were unfair to female faculty, such as a female full professor who wrote that "women faculty are slow to be considered for promotion, thereby losing thousands of dollars over the course of their careers" and a female associate professor who described the university as "a good old boy network that is difficult to navigate." A female assistant professor elaborated, writing "male faculty seem to get more favors than females...e.g., reprieve from teaching or more assistance with teaching courses. Females are just expected to get on with it and sometimes may be inhibited to ask because the answer will be "no."”

Two women, both associate professors, mentioned the gender gap in service, but had quite different understandings of it. One said that "male colleagues, I believe, are cut all sorts of slack about having children/being parents; women, not so much. Service falls disproportionately on women, but men don't 'see' it because since they aren't doing as much, they don't know that it happens." The other felt it was less deliberate, stating: "I don't think that people are targeted because they are women. I think that people who have demonstrated that they are willing to do service are asked to do more service; those types of people often happen to be women."

Thirteen faculty raised issues related to work-life conflict, and of these, 12 cared for children and 10 were women. Several mentioned policies and benefits such as the lack of maternity or paternity leave and inadequate on-campus childcare options. One male lecturer spoke for himself and his partner: "Maternity and paternity leave for faculty is not consistent across the university. My wife was pressured by her superiors to come back to teach ASAP. As the father I was not given leave."

One female assistant professor noted that she felt like an anomaly: "I am a mother and have had a lot of support to balance work and home life. However, there are few faculty who have children, which makes it seem like it "cannot be done' and also makes it harder to identify role models who have paved this path." Another professor and mother, a tenured associate professor, described the costs of professional success: "I have been productive in all areas of teaching 
research and service and got excellent evaluations. The hard part is that it has been in expense of work life family balance and even having time to take care of my health such as exercise. I have a young child."

Eleven faculty described a variety of problems with their department chairs, and 15 described problems with their deans. Issues with one's department chair or dean came up in relation to work life conflict for two faculty. One male associate professor said that "I believe that the different deans on campus have widely disparate views on work/family balance. This issue, and any other issues having to do with faculty wellbeing, is completely off the radar for my dean." A female assistant professor described how her chair advised her not to have children: "My department chair has told me several times to wait to have children until after I submit my tenure package...I am concerned about what sort of response I would receive if I informed him/her that I am pregnant when s/he told me not to get pregnant. It is very stressful, upsetting, and is causing marital problems, because my husband, who is older, also wants children."

Several faculty described their department chairs as unsupportive, including one full professor who said his chair was "directly responsible for an atmosphere of unhappiness, pressure, and stress" and a female lecturer who said "our chair can be defensive and treat my colleagues with meanness that is not necessary in the workplace." Others described their chairs or deans as poor leaders, such as a female associate professor: "I think the leadership at the chair and dean level is lacking. I have reached out to the dean to help with some chair issues and he said 'I agree with you I have no idea what to do.' What kind of leadership is that from a dean?"

One male assistant professor noted that his problems were with other faculty, not with his chair or dean: "My department chair is supportive to a point, my dean is very supportive. Other faculty tend to be more competitive than supportive and more critical than complimentary."

The vast majority of comments were not explicitly related to gender, work life conflict, or relationships with supervisors or colleagues. Rather, they focused on dissatisfaction with compensation, distrust of higher administration, and frustration with the bureaucracy. Only nine individuals described being happy with their job, even though 159 checked 'very satisfied' on the close-ended survey question. Rather, most faculty who took the time to write in optional comments had problems they wished to share, and a few were grateful someone was listening, such as one female assistant professor who simply wrote "Thank you for asking, this is the first time anybody has asked any of these questions."

\section{Discussion}

This study expands and deepens our understanding of gender inequalities among academic faculty by documenting women faculty's excess exposure to microaggressions and work-life conflict and lesser access to dean support relative to men, and how these conditions detract from their wellbeing. Using standardized survey data supplemented by openended comments, it applies stress process theory (Pearlin et al. 1981; Pearlin 1989) to examine how stressors and resources are related to academic faculty distress and job satisfaction. The results support the theory in that gender is related to differential exposure to stressors and access to resources, both of which impact faculty well-being and disadvantage women faculty. Specifically, the results indicate that women report more frequent micro-aggressions and work-life conflict, both of which are significantly associated with greater distress and less job satisfaction. Women describe their experience of microaggressions as a good old boy network in which men get special favors and get cut slack compared to women. Examples of work-life conflict and its impact on well-being include inadequate parental leave and not enough time in the day to take care of one's own health.

Women also report lower dean support, and dean support is negatively associated with distress and positively associated with job satisfaction. In addition, dean support buffers the negative association between work-life conflict and distress. Unsupportive deans are described as not even having work/life balance on their "radar" and as not being willing to intervene when faculty have problems with chairs; chairs who are blamed for creating a toxic work environment, and even going so far as to warn female faculty against having children.

Although few lesbian, gay or bisexual faculty responded to the survey, those who did reported lower job satisfaction than their heterosexual counterparts. This finding may reflect prejudice and discrimination directed towards them that is distinct from or intersects with gender (Bilimoria \& Stewart, 2009; Zurbrügg \& Miner, 2016). Faculty who identify with sexual minority groups have reported workplace incivility (Di Marco et al., 2018), behavior that shares some features with microaggressions and may also predict distress and job dissatisfaction. Future research should address the intersectionality of gender and sexual orientation in understanding the workplaces experiences of academic faculty and their wellbeing.

These findings build on research linking work-life conflict to well-being (Amstad et al., 2011; Deitch et al., 2003; Ensher et al., 2001; Frone, 2010; Oshio et al., 2017) and on the literature on micro-aggressions and mental health 
(Nadal \& Haynes, 2012; Nadal, Griffin, Wong, Hamit, \& Rasmus, 2014; Ong et al., 2013; Sellers \& Shelton, 2003; Torres et al., 2010). Since previous research has linked distress and job satisfaction to reduced worker productivity and poorer job performance (Aydogdu \& Asikgil, 2011; Colligan \& Higgins, 2006; Dovidio, 2001; Judge, Thoresen, Bono, $\&$ Patton, 2001; Robertson et al., 2012) these documented gender inequalities within academia might be indirectly perpetuated via women's disproportionate experience of micro-aggressions and work-life conflict. Future research should directly examine whether chronic exposure to micro-aggressions or work-life conflict are indirectly and negatively related to faculty performance in scholarship, service or teaching via diminished well-being.

These results suggest that institutions of higher education should strive to reduce micro-aggressions via institutional commitment to change. In academia, men and women hold unconscious implicit biases that favor white males over women (Moss-Racusin, Dovidio, Brescoll, Graham, \& Handelsman, 2012). Implicit bias training can raise faculty awareness of their gender bias and teach behaviors to promote gender equity (Carnes et al., 2012). Implicit bias training should avoid blame, engage faculty in active learning, and provide faculty with tools to help them change their behavior (Moss-Racusin et al., 2014).

Institutions of higher education should also implement steps to promote work-life balance as a means of reducing gender inequities among the faculty (Curtis, 2004), such as offering the option to stop the tenure clock. Faculty who stop the tenure-clock for family reasons are no less likely to become promoted, although they have lower salary increases over time regardless of their scholarly productivity, suggesting a negative bias towards them (Manchester, Leslie, \& Kramer, 2013). However, women faculty are less likely than men to request a tenure-clock stop even when they believe it would benefit them (Drago et al., 2006) and are reluctant to see themselves as affected by gender biases in academia (Midkiff, 2015). These findings suggest that implementing policy change is insufficient to encourage faculty to take advantage of policy options. Implicit bias training as earlier described may be necessary to reduce stereotypical thinking of women faculty who prioritize family life as less serious scholars and its impact on merit evaluations.

This study has several limitations. The data are cross-sectional and demonstrate only associations, not causal relations, and they were collected at one institution, so they do not represent other post-secondary institutions in the U.S. or in other countries. In addition, there may be a selection bias in that the faculty who chose to complete the survey were relatively motivated to report their perceptions of the campus climate, perhaps because they were relatively more distressed or dissatisfied. In addition, the sample sizes of those who identified as members of racial/ethnic minority groups or as LGB were too small to test the intersections between these statuses and gender. This is likely because racial/ethnic minorities are underrepresented on the faculty, a state of affairs that is gradually improving in response to the university's efforts to diversify such as mandated implicit bias trainings for search committee members.

Several measures in the study were adapted from other scales or developed for this study because existing scales were not designed for issues specific to academic faculty. As a result, some of the measures have no established record of reliability or validity. However, the micro-aggression items were adapted from the racial micro-aggressions scale (Mercer et al., 2011), which has been validated and shown to be reliable and generalizable. In addition, the Cronbach's alpha reliability measure for each scale was adequate, and the associations between the scales in the data were consistent with stress process theory. Taken together, the known validity and reliability of the scales from which items were drawn, the reliabilities of the scales, and the demonstrated construct validity, suggest that the scales used in this study provided sufficiently reliable data. Lastly, the study focused on perceptions of social support rather than observable usage of workplace resources.

To conclude, this study found that female faculty experience greater exposure to micro-aggressions and work-life conflict and less access to on-the-job social support both of which predict distress and job dissatisfaction. When prompted to describe these experiences in their own words, faculty provide vivid and alarming examples that beg the question of whether women's disproportionate share of these problems underlies gender inequalities in extrinsic rewards such as promotion and pay. Future research should examine whether these stressors or resources are also related directly or (indirectly via well-being) to faculty productivity. Such information could contribute to our understanding of why gender inequalities among academic faculty are so apparent and persistent.

\section{References}

American Council on Education. (2017). Women presidents. American College President Study 2017. Retrieved from https://www.aceacps.org/women-presidents/\#demographics. 
Almeida, D. M., Davis, K. D., Lee, S., Lawson, K. M., Walter, K. N., \& Moen, P. (2016). Supervisor support buffers daily psychological and physiological reactivity to work-to-family conflict. Journal of Marriage and Family, 78, 165-179. https://doi.org/10.1111/jomf.12252

Amstad, F. T., Meier, L. L., Fasel, U., Elfering, A., \& Semmer, N. K. (2011). A meta-analysis of work-family conflict and various outcomes with a special emphasis on cross-domain versus matching-domain relations. Journal of Occupational Health Psychology, 16, 151-169. https://doi.org/10.1037/a0022170

AAUP. (2018). The annual report on the economic status of the profession, 2017-18. Academe, March-April 2018.

Aydogdu, S., \& Asikgil, B. (2011). An empirical study of the relationship among job satisfaction, organizational commitment and turnover intention. International Review of Management and Marketing, 1, 43-53.

Barbezat, D. A., \& Hughes, J. W. (2005). Salary structure effects and the gender pay gap in academia. Research in Higher Education, 46, 621-640. https://doi.org/10.1007/s11162-004-4137-1

Bilimoria, D., \& Stewart, A. J. (2009). 'Don't ask, don't tell': The academic climate for lesbian, gay, bisexual, and transgender faculty in science and engineering. NWSA Journal, 21, 85-103.

Blithe, S., \& Elliott, M. (2020). Gender inequality in the academy: Microaggressions, work-life conflict, and academic rank. Journal of Gender Studies, 29, 751-764. https://doi.org/10.1080/09589236.2019.1657004

Boring, A. (2017). Gender biases in student evaluations of teaching. Journal of Public Economics, 145, 27-41. https://doi.org/10.1016/j.jpubeco.2016.11.006

Box-Steffensmeier, J. M., Cunha, R. C., Varbanov, R. A., Hoh, Y. S., Knisley, M. L., \& Holmes, M. A. (2015). Survival analysis of faculty retention and promotion in the social sciences by gender. PloS one, 10(11), e0143093. https://doi.org/10.1371/journal.pone.0143093

Cantarelli, P., Belardinelli, P., \& Belle, N. (2016). A meta-analysis of job satisfaction correlates in the public administration literature. Review of Public Personnel Administration, 36, 115-144. https://doi.org/10.1177/0734371X15578534

Carnes, M., Devine, P. G., Isaac, C., Manwell, L. B., Ford, C. E., Byars-Winston, A., Fine, E., \& Sheridan, J. (2012). Promoting institutional change through bias literacy. Journal of Diversity in Higher Education, 5, 63. https://doi.org/10.1037/a0028128

Chou, P. (2015). The effects of workplace social support on employee's subjective well-being. European Journal of Business and Management, 7(6), 8-19.

Clery, S. B., \& Christopher, B. L. (2010). Faculty salaries: 2008-2009 in The NEA.

Colligan, T. W., \& Higgins, E. M. (2006). Workplace stress: Etiology and consequences. Journal of Workplace Behavioral Health, 21, 89-97. https://doi.org/10.1300/J490v21n02_07

Cook, B. J. (2012). The American College President Study: Key findings and takeaways. American Council on Education: Leadership and Advocacy.

Curtis, J. W. (2004). Balancing work and family for faculty: Why it's important. Academe, 90, 21. https://doi.org/10.2307/40252701

Deitch, E. A., Barsky, A., Butz, R. M., Chan, S., Brief, A. P., \& Bradley, J. C. (2003). Subtle yet significant: The existence and impact of everyday racial discrimination in the workplace. Human Relations, 56, 1299-1324. https://doi.org/10.1177/00187267035611002

De Lange, A. H., Taris, T. W., Kompier, M. A. J., Houtman, I. L. D., \& Bongers, P. M. (2004). The relationships between work characteristics and mental health: Examining normal, reversed and reciprocal relationships in a 4wave study. Work \& Stress, 18, 149-166. https://doi.org/10.1080/02678370412331270860

Di Marco, D., Hoel, H., Arenas, A., \& Munduate, L. (2018). Workplace incivility as modern sexual prejudice. Journal of Interpersonal Violence, 33, 1978-2004. https://doi.org/10.1177/0886260515621083

Dovidio, J. F. (2001). On the nature of contemporary prejudice: The third wave. Journal of Social Issues, 57, 829-849. https://doi.org/10.1111/0022-4537.00244

Drago, R., Colbeck, C. L., Stauffer, K. D., Pirretti, A., Burkum, K., Fazioli, J., Lazzaro, G., \& Habasevich, T. (2006). The avoidance of bias against caregiving: The case of academic faculty. American Behavioral Scientist, 49, 12221247. https://doi.org/10.1177/0002764206286387 
Ducharme, L. J., \& Martin, J. K. (2000). Unrewarding work, coworker support, and job satisfaction: A test of the buffering hypothesis. Work and Occupations, 27, 223-243. https://doi.org/10.1177/0730888400027002005

Eagan Jr, M. K., \& Garvey, J. C. (2015). Stressing out: Connecting race, gender, and stress with faculty productivity. The Journal of Higher Education, 86, 923-954. https://doi.org/10.1353/jhe.2015.0034

Elliott, M. (2008). Gender differences in the causes of work and family strain among academic faculty." Journal of Human Behavior in the Social Environment, 17, 157-173. https://doi.org/10.1080/10911350802171039

Ensher, E. A., Grant-Vallone, E. J., \& Donaldson, S. I. (2001). Effects of perceived discrimination on job satisfaction, organizational commitment, organizational citizenship behavior, and grievances. Human Resource Development Quarterly, 12, 53-72. https://doi.org/10.1002/1532-1096(200101/02)12:1\%3C53::AID-HRDQ5\%3E3.0.CO;2-G

Fox, M. F., Fonseca, C., \& Bao, J. (2011). Work and family conflict in academic science: Patterns and predictors among women and men in research universities. Social Studies of Science, 41, 715-735. https://doi.org/10.1177/0306312711417730

Frese, M. (1999). Social support as a moderator of the relationship between work stressors and psychological dysfunctioning: A longitudinal study with objective measures. Journal of Occupational Health Psychology, 4, 179. https://doi.org/10.1037/1076-8998.4.3.179

Frone, M. R. (2010). Work-family conflict and employee psychiatric disorders: The national comorbidity survey. Journal of Applied Psychology, 85, 888-895. https://doi.org/10.1037/0021-9010.85.6.888

Ginther, D. K., \& Hayes, K. J. (2003). Gender differences in salary and promotion for faculty in the humanities 197795. Journal of Human Resources, 38, 34-73. https://doi.org/10.2307/1558755

Goh, Z., Ilies, R., \& Schwind Wilson, K. (2015). Supportive supervisors improve employees' daily lives: The role supervisors play in the impact of daily workload on life satisfaction via work-family conflict. Journal of Vocational Behavior, 89, 65-73. https://doi.org/10.1016/j.jvb.2015.04.009

Guarino, C. M., \& Borden, V. M. H. (2017). Faculty service loads and gender: Are women taking care of the academic family? Research in Higher Education, 58, 672-694. https://doi.org/10.1007/s11162-017-9454-2

Hammer, L. B., Ernst Kossek, E., Yragui, N. L., Bodner, T. E., \& Hanson, G. C. (2009). Development and validation of a multidimensional measure of family supportive supervisor behaviors (FSSB). Journal of Management, 35, 837-856. https://doi.org/10.1177/0149206308328510

Harris, J. I., Winskowski, A. M., \& Engdahl, B. E. (2007). Types of workplace social support in the prediction of job satisfaction. The Career Development Quarterly, 56, 150-156. https://doi.org/10.1002/j.21610045.2007.tb00027.x

Harvey, S. B., Modini, M., Joyce, S., Milligan-Saville, J. S., Tan, L., Mykletun, A., Bryant, R. A., Christensen, H., \& Mitchell, P. B. (2017). Can work make you mentally ill? A systematic meta-review of work-related risk factors for common mental health problems. Occupational and Environmental Medicine, 74, 301-310. https://doi.org/10.1136/oemed-2016-104015

Hirshfield, L. E. (2014). 'She's not good with crying': The effect of gender expectations on graduate students' assessments of their principal investigators. Gender and Education, 26, 601-617. https://doi.org/10.1080/09540253.2014.940036

Judge, T. A., Thoresen, C. J., Bono, J. E., \& Patton, G. K. (2001). The job satisfaction-job performance relationship: A qualitative and quantitative review. Psychological Bulletin, 127, 376-407. https://doi.org/10.1037/00332909.127.3.376

Koenig, A. M., Eagly, A. H., Mitchell, A. A., \& Ristikari, T. (2011). Are leader stereotypes masculine? A meta-analysis of three research paradigms. Psychological Bulletin, 137, 616. https://doi.org/10.1037/a0023557

Lewis, J. A., Mendenhall, R., Harwood, S. A., \& Browne Huntt, M. (2013). Coping with gendered racial microaggressions among black women college students. Journal of African American Studies, 17, 51-73. https://doi.org/10.1007/s12111-012-9219-0

Lips, H. M. (2013). Acknowledging discrimination as a key to the gender pay gap. Sex Roles, 68, 223-230. https://doi.org/10.1007/s11199-012-0245-0

Lukes, R., \& Bangs, J. (2014). A Critical Analysis of anti-discrimination law and microaggressions in academia. Research in Higher Education Journal, 24, 1-15. 
MacNell, L., Driscoll, A., \& Hunt, A. N. (2015). What's in a name: Exposing gender bias in student ratings of teaching. Innovative Higher Education, 40, 291-303. https://doi.org/10.1007/s10755-014-9313-4

Manchester, C. F., Leslie, L. M., \& Kramer, A. (2013). Is the clock still ticking? An evaluation of the consequences of stopping the tenure clock. ILR Review, 66, 3-31. https://doi.org/10.1177/001979391306600101

Mengel, F., Sauermann, J., \& Zölitz, U. (2019). Gender bias in teaching evaluations. Journal of the European Economic Association, 17, 535-566. https://doi.org/10.1093/jeea/jvx057

Mercer, S. H., Zeigler-Hill, V., Wallace, M., \& Hayes, D. M. (2011). Development and initial validation of the inventory of microaggressions against black individuals. Journal of Counseling Psychology, 58, 457-469. https://doi.org/10.1037/a0024937

Midkiff, B. (2015). Exploring women faculty's experiences and perceptions in higher education: The effects of feminism. Gender and Education, 27, 376-392. https://doi.org/10.1080/09540253.2015.1028902

Misra, J., Hickes Lundquist, J., Holmes, E., \& Agiomavritis, S. (2011). The ivory ceiling of service work. Washington: American Association of University Professors.

Moeller, C., \& Chung-Yan, G. A. (2013). Effects of social support on professors' work stress. International Journal of Educational Management, 27, 188-202. https://doi.org/10.1108/09513541311306431

Monroe, K., Ozyurt, S., Wrigley, T., \& Alexander, A. (2008). Gender equality in academia: Bad news from the trenches, and some possible solutions. Perspectives on Politics, 6, 215-233. https://doi.org/10.1017/S1537592708080572

Moss-Racusin, C. A., Dovidio, J. F., Brescoll, V. L., Graham, M. J., \& Handelsman, J. (2012). Science faculty's subtle gender biases favor male students. Proceedings of the National Academy of Sciences, 109, 16474-16479. https://doi.org/10.1073/pnas.1211286109

Moss-Racusin, C. A., van der Toorn, J., Dovidio, J. F., Brescoll, V. L., Graham, M. J., \& Handelsman, J. (2014). Scientific Diversity Interventions. Science, 343(6171), 615-616. https://doi.org/10.1126/science. 1245936

Nadal, K. L., Griffin, K. E., Wong, Y., Hamit, S., \& Rasmus, M. (2014). The impact of racial microaggressions on mental health: Counseling implications for clients of color. Journal of Counseling \& Development, 92, 57-66. https://doi.org/10.1002/j.1556-6676.2014.00130.x

Nadal, K. L. \& Haynes, K. (2012). The effects of sexism, gender micro-aggressions, and other forms of discrimination on women's mental health and development. Women and Mental Disorders, 1, 4.

National Science Foundation. (2015). Women, minorities, and persons with disabilities in science and engineering: 2015 digest. National Center for Science and Engineering Statistics, Directorate for Social, Behavioral and Economic Sciences: Alexandria, VA.

Ong, A. D., Burrow, A. L., Fuller-Rowell, T. E., Ja, N. M., \& Sue, D. W. (2013). Racial microaggressions and daily well-being among Asian Americans. Journal of Counseling Psychology, 60, 188-199. https://doi.org/10.1037/a0031736

Oshio, T., Inoue, A., \& Tsutsumi, A. (2017). Does work-to-family conflict really matter for health? Cross-sectional, prospective cohort and fixed-effects analyses. Social Science \& Medicine, 175, 36-42. https://doi.org/10.1016/j.socscimed.2016.12.039

Pearlin, L. I. (1989). The sociological study of stress. Journal of Health and Social Behavior, 30, 241-256. https://doi.org/10.2307/2136956

Pearlin, L., Menaghan, E. G., Lieberman, M. A., \& Mullan, J. T. (1981). The stress process. Journal of Health and Social Behavior, 22, 337-356. https://doi.org/10.2307/2136676

Perna, L. W. (2005). Sex differences in faculty tenure and promotion: The contribution of family ties. Research in Higher Education, 46, 277-307. https://doi.org/10.1007/s11162-004-1641-2

Perna, L. W. (2001). Sex and race differences in faculty tenure and promotion. Research in Higher Education, 42, 541567. https://doi.org/10.1023/A:1011050226672

Pittman, C. T. (2012). Racial microaggressions: The narratives of African American faculty at a predominantly White university. The Journal of Negro Education, 81, 82-92. https://doi.org/10.7709/jnegroeducation.81.1.0082 
Robertson, I. T., Jansen Birch, A., \& Cooper, C. L. (2012). Job and work attitudes, engagement and employee performance: Where does psychological well-being fit in? Leadership \& Organization Development Journal, 33 , 224-232. https://doi.org/10.1108/01437731211216443

Savigny, H. (2014). Women, know your limits: Cultural sexism in academia. Gender and Education, 26, $794-809$. https://doi.org/10.1080/09540253.2014.970977

Schmaling, K. B. (2007). Gender microaggressions in higher education: Proposed taxonomy and change through cognitive-behavioral strategies. Forum on Public Policy: A Journal of the Oxford Round Table, 3, n3.

Schimanski, L. A., \& Alperin, J. P. (2018). The evaluation of scholarship in academic promotion and tenure processes: Past, present, and future. F1000Research, 7. https://doi.org/10.12688/f1000research.16493.1

Sellers, R. M., \& Shelton, J. N. (2003). The role of racial identity in perceived racial discrimination. Journal of Personality and Social Psychology, 84, 1079-1092. https://doi.org/10.1037/0022-3514.84.5.1079

Shen, H. (2013). Mind the gender gap. Nature, 495(7439), 22. https://doi.org/10.1038/495022a

Shulman, S., Hopkins, B., Kelchen, R., Persky, J., Yay, M., Barnshaw, J., \& Dunietz, S. J. (2017). Visualizing change: The annual report on the economic status of the profession, 2016-17. Washington: American Association of University Professors.

Stansfeld, S., \& Candy, B. (2006). Psychosocial work environment and mental health-a meta-analytic review. Scandinavian Journal of Work, Environment \& Health, 32, 443-462. https://doi.org/10.5271/sjweh.1050

Stewart, A. L., Ware, J. E., Sherbourne, C. D., \& Wells, K. B. (1992). Psychological distress/well-being and cognitive functioning measures. In, A. L. Stewart \& J. E. Ware (Eds.), Measuring Functioning and Well-being: The Medical Outcomes Study Approach (pp. 102-142). Durham, NC: Duke University Press. https://doi.org/10.7249/CB361

Sue, D. W., Capodilupo, C. M., Torino, G. C., Buccer, J. M., Holder, A., Nadal, K. L., \& Esquilin, M. (2007). Racial microaggressions in everyday life: Implications for clinical practice. American Psychologist, 62, 271-286. https://doi.org/10.1037/0003-066X.62.4.271

Terry, D. J., Nielsen, M., \& Perchard, L. (1993). Effects of work stress on psychological well-being and job satisfaction: The stress-buffering role of social support. Australian Journal of Psychology, 45, 168-175. https://doi.org/10.1080/00049539308259135

Thornton, S. (2010). No refuge: The annual report on the economic status of the profession. Academe, 96, 3-80.

Torres, L., Driscoll, M. W., \& Burrow, A. L. (2010). Racial microaggressions and psychological functioning among highly achieving African-Americans: A mixed-methods approach. Journal of Social and Clinical Psychology, 29, 1074-1099. https://doi.org/10.1521/jscp.2010.29.10.1074

Triana, M., Jayasinghe, M., \& Pieper, J. R. (2015). Perceived workplace racial discrimination and its correlates: A meta-analysis. Journal of Organizational Behavior, 36, 491-513. https://doi.org/10.1002/job.1988

Van der Doef, M., \& Maes, S. (1999). The job demand-control (-support) model and psychological well-being: A review of 20 years of empirical research. Work \& Stress, 13, 87-114. https://doi.org/10.1080/026783799296084

Weisshaar, K. (2017). Publish and perish? An assessment of gender gaps in promotion to tenure in academia. Social Forces, 96, 529-560. https://doi.org/10.1093/sf/sox052

Wolfinger, N. H., Mason, M. A., \& Goulden, M. (2008). Problems in the pipeline: Gender, marriage, and fertility in the ivory tower. The Journal of Higher Education, 79, 388-405. https://doi.org/10.1080/00221546.2008.11772108

Zurbrügg, L., \& Miner, K. N. (2016). Gender, sexual orientation, and workplace incivility: Who is most targeted and who is most harmed? Frontiers in Psychology, 7, 565. https://doi.org/10.3389/fpsyg.2016.00565

\section{Copyrights}

Copyright for this article is retained by the author(s), with first publication rights granted to the journal.

This is an open-access article distributed under the terms and conditions of the Creative Commons Attribution license (http://creativecommons.org/licenses/by/4.0/). 